Does the government need to compromise? To keep the political peace it may choose to do so, but other options are open to it, including encouragement for the partial privatisation of general practice, as with dentistry. The General Medical Services Committee may cherish the ostensible unity of general practice, but market logic drives us towards fragmentation and division, and the schisms within the profession described by Keighley in this issue ( $p$ 977) ${ }^{8}$ may fuel that process.

The provider friendly contract outlined by Ian Bogle emphasises the practice rather than the individual general practitioner as the provider and seeks to make delegation of work to other professionals more secure. It also dissects current workload into core general medical services (within normal working hours), out of hours services, and special services such as minor surgery, dispensing, and needs assessment for community care. ${ }^{1}$ Local negotiation would deal with local variations, and practices would be given a budget for services, staff, prescribing, and development. Quality control would be established through regular practice review and professional reaccreditation.

Would it work? It probably would in the shires, but perhaps not in the cities. Franchise general practice develops best when rising demand meets growing resources, ${ }^{9}$ but again it develops better in market towns than in urban areas. Resources are promised for general practice, but demand is already rising, partly for demographic reasons, ${ }^{10}$ but also because economic depression creates morbidity. ${ }^{11}$

With the proposed model the best practices with the most ambitious programmes for staff growth and service development will compete with their weary and lacklustre neighbours for resources from the same pool. It is difficult to see how the new proposals will eliminate variations in the quality of care. They may in fact exacerbate them, as weak practices become relative losers.

An alternative view identifies general practitioners' autonomy as the source of unacceptable variation in standards of care, ${ }^{12}$ and emphasises management, planning, and salaried general practice integrated into a broader primary care framework. ${ }^{13}$ In cities this approach may be more practicable than the traditional model of independent contractors and if adequately resourced may allow rapid improvement in service quality. The General Medical Services Committee might usefully take a pluralistic approach and develop a model for salaried practice.

General practice is on the defensive, but it still has several options for the future. The debate initiated by Bogle's controversial paper is necessary, and for the first time in 20 years of GMSC politics we cannot predict the outcome. Given general practitioners' longstanding hostility to control and the poor prospects for the economy and the NHS, the way forward for general practice looks long and difficult.

STEVE ILIFFE Senior clinical lecture

Department of Primary Health Care,

University College and Middlesex School of Medicine,

Whittington Hospital,

London N19 5NF

\footnotetext{
General Medical Services Committee. General practice: which way forward? A GMSC discussion document. London: General Medical Services Committee, 1993.

Hart Restoring professionalism to general practice. BMf 1993;306:608.

3 Royal College of General Practitioners. Evidence to the Royal Commission on the National Health Service. IRoyal Coll Gen Pract 1977;27:197-206.

4 General Medical Services Committee. General practice: a British success. London: General Medical Services Committee, 1983.

5 Iliffe $S$. Thinking through a salaried service for general practice. $B M F$ 1992;304: 1456-7.

6 Sutherland VJ, Cooper CL. Job stress, satisfaction and mental health among general practitioners before and after introduction of new contract. $B M 7$ 1992;304:1545-8.

Stanworth J, Smith B. Franchising for the small business. Oxford: Blackwell, 1991.

8 Keighley B. The RCGP revisited. BMF 1993;306:977-8.

9 Bosanquet N, Leese B. Family doctors and economic incentives. Aldershot: Dartmouth, 1989.

10 Frischer $M$. Trends in morbidity and general practitioners' workload for middle-aged and elderly people from 1956 to 1982. I Public Health Med 1991;13:198-203.

1 Beale N, Nethercott S. Job loss and family morbidity: a study of factory closure. $\mathcal{f} R$ Coll Gen Pract 1985;280:510-4.

12 Hart JT. A new kind of doctor. London: Merlin, 1988:157.

13 Medical Practitioners Union. The future of primary care. London: Medical Practitioners Union, 1992.
}

\title{
Where are we now with vaccines against AIDS?
}

\author{
Awaiting large scale trials of efficacy
}

Intense activity has been devoted to developing an effective vaccine for AIDS in the decade since HIV was identified as the causal agent. ${ }^{1}$ As in most scientific endeavours, there have been exciting advances, as well as setbacks and disappointments. Nevertheless, the results of extensive studies in experimental animal models and phase I and II clinical trials in humans provide some grounds for cautious optimism that effective vaccines against AIDS can be produced.

Simian immunodeficiency virus (SIV) induces in macaque monkeys a lethal disease indistinguishable from the disease induced by HIV in humans. In this model, over 200 monkeys have been protected by simple inactivated vaccines against infection with a lethal challenge dose of SIV. ${ }^{23}$ These inactivated vaccines protected against a wide range of antigenic types of SIV given intravenously and also against challenge by a mucosal route. ${ }^{45}$ The optimism generated by these early successes was tempered, however, by the subsequent and totally unexpected discovery that most, if not all, of the protection observed was due to human $T$ cell antigens in the vaccines and challenge viruses and not to SIV components. ${ }^{6} \mathrm{~A}$ further sobering finding is that most attempts to protect macaques against SIV by using purified recombinant proteins derived from either the envelope or core of SIV have been unsuccessful even though some of these antigens stimulated good SIV neutralising antibody and cellular immune responses. $^{78}$

Nevertheless, there is evidence that macaques can be protected by immune responses to the virus. Passive transfer of antibody to SIV has convincingly been shown to prevent infection. ${ }^{9}$ Vaccination with live recombinant vaccinia virus expressing SIV envelope followed by purified gp 160 has been shown to protect against a biological clone of SIV that is genetically identical with the vaccine's composition. ${ }^{10}$ Most recently and most dramatically, vaccination with attenuated live SIV with a deletion in the regulatory nef gene protected against a challenge with 1000 monkey infectious doses of virus. " Thus data from the SIV macaque model indicate that viral antigens can induce protection but that the immunity induced by purified recombinant proteins is unlikely to extend to a wide range of antigenic types.

Studies in chimpanzees have so far been limited to the classic laboratory IIIB strain of HIV-1, which is unrepresentative of the strains circulating in the general population. Nevertheless, further encouraging results have emerged from 
this system. Purified recombinant envelope protein either as the gp120 surface unit ${ }^{12}$ or as the entire gpl60 protein has protected a proportion of chimpanzees against infection. Chimpanzees have also been protected by a complex regimen of vaccinations involving inactivated virus and peptides analogous to the third variable domain of the envelope protein. This vaccine protected not only against cell free virus but also against chimpanzee lymphocytes infected with virus. ${ }^{13}$ Finally, passive transfer of a humanised monoclonal antibody to this third hypervariable domain also protected against challenge with live virus. ${ }^{14}$ New stocks of HIV based on strains more relevant than IIIB have been prepared for challenge in chimpanzees and are currently being titrated in vivo in the United States. Whether earlier successes in this system can be repeated with viruses more closely related to those causing AIDS in the United States and Africa remains to be seen.

Substantial advances have also been achieved in phase I clinical trials in human volunteers. ${ }^{15}$ Several experimental immunogens have been tested in phase I and II trials of safety and immunogenicity. Five different recombinant HIV envelope subunits, produced in yeast, insect, or mammalian cells, have been used. In addition, trials have been conducted with live recombinant vaccinia virus expressing HIV envelope or with synthetic peptides or virus-like particles derived from yeast but expressing HIV core proteins. The vaccines have proved safe, and fears that HIV envelope antigens would cause autoimmune phenomena by molecular mimicry have so far proved unfounded. Dose range studies of subunit HIV antigens in alum generally indicate that large quantities of the antigens are required and the humoral immune responses are short lived. Alternative antigen adjuvant formulations are being tested. The gag antigens studied have induced cellular immune responses, which may be important for clearing HIV infected cells and for priming the immunological memory. Trials with the live recombinant vaccinia virus expressing HIV envelope represent the first use of live recombinant virus in humans. Further studies are currently under way in France with an avian poxvirus vector, which is host restricted and therefore potentially safer. Finally, studies with combinations of live recombinant virus vaccines followed by immunisation with purified subunits indicate that this approach may stimulate both cellular immunity and neutralising antibodies at higher concentrations than have previously been observed or obtained.

The stage is now set to prepare for large scale trials of the efficacy of AIDS vaccines. The World Health Organisation has identified four sites in Brazil, Rwanda, Thailand, and Uganda and has begun to establish the infrastructure and to accumulate the epidemiological data necessary for such trials. The US Congress has recently allocated $\$ 20 \mathrm{~m}$ to the US Army to conduct a phase III trial of efficacy.

But these moves present a dilemma, for it is by no means clear which of the candidate vaccines should be chosen for such trials. Data from the animal experiments do not identify unequivocally any one of the candidate vaccines. Similarly, studies of the natural course of HIV infections have failed to identify correlates of immunity or disease progression. These pressures may, at least in part, be behind the recent decision to compare three of the candidate envelope vaccines in small scale trials of efficacy in pregnant mothers and young children, in whom indication of effectiveness might be obtained relatively quickly. ${ }^{16}$ The worldwide AIDS epidemic continues to grow inexorably and exponentially. The need is urgent, and the window of opportunity for effective vaccination is limited. Large scale efficacy trials will almost certainly begin within five years. Studies in animal models and human volunteers must continue so that the choices of vaccines may be informed by the best available scientific information. Most people believe that a successful AIDS vaccine will come, but few are prepared to predict how soon.

G C SCHILD Director

EJSTOTT

National Institute for Biological

Head, AIDS Collaborating Centre

Standards and Control,

Potters Bar,

Hertfordshire EN6 3QG

1 Barre-Sinoussi F, Chermann JC, Rey F, Nugeyre MT, Chamaret S, Gruest J, et al. Isolation of a T-lymphotropic retrovirus from a patient at risk for acquired immune deficiency syndrome (AIDS). Science 1983;220:868-71.

2 Desrosiers RC, Wyand MS, Kodama T, Ringler DJ, Arthus LO, Sehgal PK, et al. Vaccine protection against simian immunodeficiency virus infection. Proc Natl Acad Sci USA 1989;86: 6353-7.

3 Murphey-Corb M, Martin LN, Davison-Fairburn B, Montelero RC, Miller M, West M, et al. A formalin inactivated whole SIV vaccine confers protection in macaques. Science 1989;246: 1293-7.

4 Stott EJ, Cranage MP, Kitchin PA, Kent K, Farrar G, Taffs LF. Vaccination against simian immunodeficiency virus infection of macaques. In: Girard M, Vallette L, eds. Sixieme colloque des cent gardes. Lyon: Foundation Marcil Merieux, 1991:261-6.

5 Cranage MP, Baskerville A, Ashworth LAE, Dennis M, Cook N, Sharpe S, et al. Intrarectal challenge of macaques vaccinated with formalin-inactivated simian immunodeficiency virus. Lancet 1992;339:273-4.

6 Stott EJ, Kitchin PA, Page M, Flanagan B, Taffs LF, Chan WL, et al. Anti-cell antibody in macaques. Nature 1991;353:393.

7 Mills KHG, Page M, Chan WL, Kitchin P, Stott EJ, Taffs LF, et al. Protection against SIV infection in macaques by immunisation with inactivated virus from BK28 molecular clone, but infection in macaques by immunisation with inactivated virus from BK28 molecular

8 Giavedoni LP, Planelles V, Haigwood NL, Ahmed S, Kluge JD, Marthas ML, et al. Immune response of rhesus macaques to recombinant simian immunodeficiency virus gp 130 does not protect from challenge infection. $\mathcal{F}$ Virol 1993;67:577-83.

9 Putkonen P, Thorstensson R, Ghavamzadeh L, Albert J, Hild K, Biberfeld G, et al. Prevention of HIV-2 and IV infection by passive immunisation in cynomolgus monkeys. Nature 1991;352: 436-8.

10 Hu S-L, Abrauss K, Barber GN, Moran P, Zarling JM, Langlois AJ, et al. Protection of macaques against SIV infection by subunit vaccines of SIV envelope glycoprotein gp 160. Science 1992;255: 456-9.

11 Daniel MD, Kirchoff F, Czajak SC, Sehgal PK, Desrosiers RC. Protective effects of a live attenuated SIV vaccine with a deletion in the nef gene. Science 1992;258:1938-41

12 Berman PW, Gregory TJ, Riddle L, Nakamera GR, Champe MA, Porter JP, et al. Protection of chimpanzees from infection of HIV-1 after vaccination with recombinant gp120 but not $\mathrm{pg} 160$. Nature 1990;345:622-5.

13 Fultz PN, Nara P, Barre-Sinoussi F, Chaput A, Greenberg ML, Muchmore E, et al. Vaccine protection of chimpanzees against challenge with HIV-1 infected peripheral blood mononuclear protection of chimpanzees against

14 Emini EA, Schleif WA, Nunberg JH, Conley AJ, Eda Y, Tokiyoshi S, et al. Prevention of HIV-1 infection in chimpanzees by gp120 V3 domain-specific monoclonal antibody. Nature 1992;355: 728-30.

15 Kazon DT, Bolognesi DP, Koff WC. Development of a vaccine for the protection of AIDS, a critical appraisal. Vaccine 1992;10:1039-52.

16 Cohen J. Pediatric AIDS vaccine trials set. Science 1992;258:1568-70. 